\title{
Framing the \#0ccupy Nigeria Protests in Newspapers and Social Media
}

\author{
Nwachukwu Egbunike \\ Department of Communication and Language Arts, University of Ibadan, Ibadan, Nigeria \\ Email: nwachukwuegbunike@gmail.com
}

Received 10 April 2015; accepted 27 April 2015; published 6 May 2015

Copyright (C) 2015 by author and OALib.

This work is licensed under the Creative Commons Attribution International License (CC BY). http://creativecommons.org/licenses/by/4.0/

(C) (i) Open Access

\begin{abstract}
Nigeria witnessed \#Occupy Nigeria Protests in January 2012, following government's removal of subsidy on premium motor spirits. This study looked at the frames employed by the old and new media respectively in the \#0ccupy Nigeria Protest. The three collective action frame building tasks proposition of the framing theory: motivation, diagnosis and prognosis were employed in the content analysis of the samples. The three national newspapers were Nigerian Tribune, the Guardian and the Punch while the social media samples were an Occupy Nigeria Facebook page, blog posts, conversations in Nairaland and Twitter. Findings revealed that newspapers were better than social media in framing the motivation, diagnosis and prognosis of the protest. It also showed that the newspapers presented a more heterogeneous narration of the protest. This study holds that newspapers are better contributors to the discourse of the \#Occupy Nigeria Protests than social media.
\end{abstract}

Keywords

\#Occupy Nigeria Protests, Media Framing, Old Media, New Media, Social Movements

Subject Areas: Journalism and Communication

\section{Introduction}

The Occupy Nigeria Protests were a collective rejection of the Nigerian Government's sudden increase of Premium Motor Spirits (PMS) from N65 to N140. This national outburst coincidentally took place at the heels of Global Occupy Protests and the Arab Spring. Like in these two uprisings, the social media forced international media attention on Nigeria [1]. As such, it was not unusual that the Nigerian protest was initially perceived as a continuation of the global protests against government high handedness which had commenced with the Arab Spring [2]-[10].

The Nigerian government had based her argument of subsidy removal on channelling of the gains of subsidy 
to develop other sectors of the economy [11]. And the other reason was that major distributors after claiming subsidy for PMS would go ahead to supply the same product to the illegal petroleum markets in neighbouring countries at exorbitant costs. The government was inadvertently subsidizing corruption and yet unable to make PMS available for Nigerians [12].

However, neither labour nor civil society accepted the propositions by the establishment. Besides, decades of continuous "broken promises" by government made these apparently sound economic reasons difficult to swallow by ordinary Nigerians [13]. On 1st January, 2012, Government went ahead and removed the subsidy. The effect of the withdrawal of subsidy was immediate, with transportation fares across the country soaring as high as 120\% [14]-[16]. The resultant effect was an astronomical rise in the cost of living. Nigerians felt bad that the only "social security" available was withdrawn and untold hardship and frustration foisted on them [17]. Thus labour and civil society demanded an immediate reversal of the subsidy removal but government did not bulge. So on January 9, 2012, the Occupy Nigeria Protests started across the country and lasted officially for over two weeks.

This study will examine how three national newspapers: Guardian, Punch and the Nigerian Tribune framed the Occupy Nigeria protest. It will also compare these frames from the print media with those from four social media platforms: Twitter, Facebook, Nairaland and blog posts. The aim of this comparative analysis of both old and new media will be to determine which media—old or new—portray the protests better. To the best of our knowledge, no empirical research has investigated this yet and as such the problematic rhetoric of a revolution propelled by social media needs further investigation.

\section{Theoretical Background}

Framing is a theoretical framework in a process of evolution. Frames are the particular treatment or "spin" given to a message by an individual or organization [18]. While agenda-setting is choosing which stories to tell, framing is choosing how to tell them [19]. Framing calls "attention to some aspects of reality while obscuring other elements, which might lead audiences to have different reactions" [20]. The media provides "windows" for audiences to "understand" an issue. Expectation then is that the more media you consume-about the same issuethe more windows you encounter

Scholarly investigation on framing and social movements shows that "the framing processes have come to be regarded, alongside resource mobilization and political opportunity process, as a central dynamic in understanding the character and course of social movements" ([21]; p. 611). Collective action frames defines but also inspires and validates the organization and activities of SMOs. As cited earlier Benford and Snow [21] proposed three core framing tasks. Diagnostic frames ask the question: what is the cause of the problem? Prognostic framing aims at finding a solution while motivational framing defines and spurs mobilization, necessary for validation/legitimacy of campaigns by SMOs.

The significance of framing theory lies in its importance in a developing nation like Nigeria where the democratic experience is still being tested. Within the context of Occupy Nigeria Protest, this study hopes to add to the global conversation of framing theory.

\section{Mass Media, Social Media, Social Movements and the Arab Spring}

The relationship between SMOs and mass media is imbalanced, with media often distorting the message of movements. This asymmetrical dependency is seen in mass media preference for catchy headlines which promotes the deviant behaviour of protesters for instance. Thus media frames tend to ignore the message of SMO but rather hype sensational outbursts [22]-[24], and as discussed elsewhere in Gitlin [18]. Yet, media attention is absolutely important for movements to mobilize but negative frames do not and cannot sell the movements since they diminish public support. In addition, it weakens the collective identity of the protesters since the "we" against "them" is necessary to ignite and sustain a protest.

The new media affords movements an opportunity to sidestep media gatekeepers [25]-[29]. Yet this was not always the case, as alternative media created some new problems for movements. For instance, mass self-communication generates a digital echo chamber of same minds, using the same platform but thinking that they are communicating with "many" people, Castells [25].

There is some disagreement in scholarly research of the role of social media in the Arab Spring [30]-[34]. Chebib and Sohail [36] ascribed a strong causal role to Facebook and Twitter in the Egyptian revolt but such a 
narrative is now challenged as simplistic. Others provided a historical context of revolt in Egypt which showed that social media, just like Al Jazerra and interpersonal communication, contributed their due to the Arab Spring, as quoted earlier in Olorunnisola and Martin [31], Tufekci and Wilson [33]. Many scholars insisted that dead, jailed or injured Egyptians could have been mobilized through social media (or through any other medium). As such, it would be unrealistic to infer that "Facebook or Twitter" was solely responsible for the decision to protest [37] [38].

In summary, whilst a study of the Egyptian uprising revealed varying ideological positions on the role of social media, it did signify its growing power not only for agenda setting but also for framing in such social engagements. An analysis of the different roles of traditional media and social media in the Occupy Nigeria movement should enable us see the roles these two media played in framing.

\section{Methods}

A qualitative content analysis on the \#Occupy Nigeria Protest (January 9 and 16, 2012) using manually filtered purposive sampling of news stories and opinion columns of newspapers (old media) and posts from social media sites published between January 9 and 31, 2012 was conducted. The date of samples studied was extended to capture stories after January 16, when labour pulled out officially from the protests. However, civil society groups continued their protests till the end of January.

The three Nigerian newspapers were: The Guardian, the Punch and the Nigerian Tribune. For the social media we analyzed: Facebook Group: "Nationwide Anti-Fuel Subsidy Removal: Strategies and Protests". Twitter feeds of the Occupy Nigeria Protests: the tweets were derived from \#Occupy Nigeria and \#fuel subsidy. Due to the one year anniversary of the Occupy Nigeria Protest in 2013 the entire tweet feed-which had earlier disappeared - became available. Blog posts: a Google search for "\#Occupy Nigeria Protests" and "fuel subsidy removal Nigeria protest" was conducted and also Comments on Nairaland: an online discussion platform. Holsti's [39] formula for the reliability of nominal data in terms of percentage of agreement was used and the inter-coder reliability index was approximately 0.8 .

\section{Findings}

This paper proposes three research questions to uncover how Nigerian newspapers and the social media framed the Occupy Nigeria Protest. They are: (1) How was the definition of Occupy Nigeria Protests framed in newspapers and social media? (2) How were the causes of the Occupy Nigeria Protests framed in newspapers and social media? (3) How were solutions advocated to end the Occupy Nigeria Protests framed in newspapers and social media?

\section{How Was the Definition of Occupy Nigeria Protests Framed in Newspapers and Social Media?}

Twelve pre-determined content categories were coded for social media and newspapers respectively: dictatorship by government; corruption in the petroleum industry; excessive government expenditure; oppression and insensitivity. The others are: foreign influence; opposition political groups; mass movement; generational transfer; revolution and ethnic/religious. The total texts analyzed in social media were: blogs (218), Nairaland (193), Tweets (818) and Facebook (118). The three newspapers had a total count of 520 for Punch, 488 for Guardian and 415 for Nigerian Tribune. Table 1 shows how the protest was defined in the various newspapers and social media platforms.

\section{How Social Media Defined the Occupy Nigeria Protest?}

As shown in Table 1, mass movement was the dominant frame in social media platforms. Results revealed that tweets ranked first with 54.4\%, followed by comments in Nairaland (47.2\%) and Facebook (29.7\%), while blogs had $17.9 \%$ of their news articles defining the Occupy Nigeria Protests as a mass movement.

The qualitative data from the four social media platforms also defined the protest as a mass movement. For instance, Ogunyemi Olaitan Bukola said on Facebook: "Comrades, wake up early tomorrow Friday, January 6th, and MARCH down to Olaiya Roundabout in Osogbo by $8 \mathrm{am}$. It's time to make OUR voices heard; it's time to make OUR will hold!” These comments on Nairaland defined the protest as "peaceful demonstrations" and not "riots": "Ogugua88: this is the brand of the movement. Anyone in Nigeria, I urge you to go. ...Please note, these are peaceful demonstrations, not riots!" Another NL commentator shared the following-Honeric01: "Less than 700,000 armed personal against more than 50 million people nationwide, we go see who go run.” 
Table 1. Definition of the occupy Nigeria protest in social media and newspapers.

\begin{tabular}{|c|c|c|c|c|c|c|c|c|c|c|c|c|c|c|}
\hline & \multicolumn{8}{|c|}{ Social Media } & \multicolumn{6}{|c|}{ Newspapers } \\
\hline & \multicolumn{2}{|c|}{ Blogs } & \multicolumn{2}{|c|}{ Nairaland } & \multicolumn{2}{|c|}{ Tweet } & \multicolumn{2}{|c|}{ Facebook } & \multicolumn{2}{|c|}{ Punch } & \multicolumn{2}{|c|}{ Guardian } & \multicolumn{2}{|c|}{ Tribune } \\
\hline & $\mathrm{N}$ & (\%) & $\mathrm{N}$ & (\%) & $\mathrm{N}$ & (\%) & $\mathrm{N}$ & $(\%)$ & $\mathrm{N}$ & (\%) & $\mathrm{N}$ & (\%) & $\mathrm{N}$ & (\%) \\
\hline Dictatorship & 9 & 4.1 & 0 & 0.0 & 9 & 1.1 & 2 & 1.7 & 12 & 2.3 & 12 & 2.5 & 26 & 6.3 \\
\hline Corruption & 22 & 10.1 & 16 & 8.3 & 35 & 4.3 & 8 & 6.8 & 42 & 8.1 & 49 & 10.0 & 23 & 5.5 \\
\hline Excess Spending & 15 & 6.9 & 9 & 4.7 & 23 & 2.8 & 9 & 7.6 & 27 & 5.2 & 32 & 6.6 & 4 & 1.0 \\
\hline Oppression & 17 & 7.8 & 18 & 9.3 & 52 & 6.4 & 6 & 5.1 & 59 & 11.3 & 48 & 9.8 & 39 & 9.4 \\
\hline Poverty & 29 & 13.3 & 10 & 5.2 & 16 & 2.0 & 16 & 13.6 & 50 & 9.6 & 64 & 13.1 & 59 & 14.2 \\
\hline Insensitivity & 30 & 13.8 & 9 & 4.7 & 16 & 2.0 & 6 & 5.1 & 46 & 8.8 & 62 & 12.7 & 49 & 11.8 \\
\hline Foreign Influence & 8 & 3.7 & 6 & 3.1 & 10 & 1.2 & 6 & 5.1 & 9 & 1.7 & 9 & 1.8 & 6 & 1.4 \\
\hline Opposition Party & 6 & 2.8 & 0 & 0.0 & 1 & 0.1 & 1 & 0.8 & 20 & 3.8 & 8 & 1.6 & 19 & 4.6 \\
\hline Mass Movement & 39 & 17.9 & 91 & 47.2 & 445 & 54.4 & 35 & 29.7 & 223 & 42.9 & 174 & 35.7 & 175 & 42.2 \\
\hline Generation Transfer & 22 & 10.1 & 12 & 6.2 & 154 & 18.8 & 10 & 8.5 & 17 & 3.3 & 18 & 3.7 & 11 & 2.7 \\
\hline Revolution & 12 & 5.5 & 8 & 4.1 & 10 & 1.2 & 1 & 0.8 & 11 & 2.1 & 7 & 1.4 & 3 & 0.7 \\
\hline Unity & 9 & 4.1 & 14 & 7.3 & 47 & 5.7 & 18 & 15.3 & 4 & 0.8 & 5 & 1.0 & 1 & 0.2 \\
\hline Total & 218 & 100.0 & 193 & 100.0 & 818 & 100.0 & 118 & 100.0 & 520 & 100.0 & 488 & 100.0 & 415 & 100.0 \\
\hline
\end{tabular}

The second prominent motivation frame elected by social media was "generational transfer": the mean value from Table 1 yielded 198 (14.8\%) for social media and 46 (3.2\%) for newspapers. This contrasts with the second best of newspapers which was "poverty" 173 (12.2\%) as against 71 (5.3\%) for social media. These are excerpts from two blog posts: "We young Nigerians want a change and we want it now. We demand for proper security of lives and properties across the entire nation and say A LOUD NO TO SUBSIDY REMOVAL" (Nigerian Students, Youths and other Professionals in the United Kingdom, "\#Occupy Nigeria London—Fuel Subsidy Petition to President 'Good' luck Jonathan sent through the Nigeria High Commission in London”, Friday, 6th January 2012). The tool the youths employed was social media: "Twitter rants and rebuffs abound. Also locally trending on Twitter are the all-important updates on the Occupy Nigeria movement around the country. Cyber-activists have also hacked into government agency sites, replacing their web pages with 'Occupy Nigeria'” (Philanterprise, “\#Occupy Wall Street...Nigeria...Then?” January 14, 2012).

\section{How Newspapers Defined the Occupy Nigeria Protest?}

The three newspapers prominently defined the protest as a mass movement: Punch (42.9\%), Guardian (35.7\%) and Nigerian Tribune (42.2\%). This Guardian headlines is precise with the number of protesters in Abuja:

The President of Trade Union Congress (TUC) Peter Esele told the crowd at the "Freedom Square" in

Wuse Zone Four that Labour would mobilise 100,000 protesters for today's demonstrations. ...At Monday's rally there were about 20,000 demonstrators but the number rose to about 40,000 according to data released by Labour (Oghoghe Obaywanna, John Ogbodo, Collins Olayinka, Seye Olumide and Tunde Akinola, The Guardian, January 11, 2012, p. 1).

The Punch, for instance, emphasized oppression (11.3\%), poverty (9.6\%) and insensitivity (8.8\%) as second main themes. For Guardian, it was poverty (13.1\%), insensitivity (12.7\%) and corruption (10\%). The Nigerian Tribune reported poverty (14.2\%), insensitivity (11.8\%) and oppression (9.4\%). For instance, the Nigerian Tribune revealed the poverty frame (financial hardship) as shown in the hike in transportation fares:

Investigation by the Nigerian Tribune showed that fares had doubled, with commuters travelling to Lagos from Asaba paying as much as N5000; from Asaba to Benin N1000 while those returning to Abuja or Kano paid N8000 and N10,000 respectively, depending on comfort of the vehicle [...] Also, intra-city and intercity fares went up by 100 per cent (Our Reporters, Nigerian Tribune, January 2, 2012, p. 1-2). 
The financial hardship as shown in the quote above has basis of credibility. Nigerian writer, Chimamanda Adichie wrote:

On New Year's Day, in my ancestral hometown of Abba in Anambra State in eastern Nigeria, my family and I woke up to unbelievable news: the price of petrol had doubled. Almost immediately, transport fares exploded and food prices rose astronomically. It used to cost 4000 naira—about $\$ 25$ - to fill my petrol tank. Then it cost 10,000 naira [40].

We will end this section by looking at the "opposition party" frame. The ruling People's Democratic Party (PDP) accused the opposition politicians of instigating the protests. A PDP Chieftain warned: "Organized labour and the civil society groups must not allow dangerous elements in the society to exploit their legitimate protests and rallies to attempt an assault on the unity of Nigeria People" (Nigerian Tribune, "Babatope Canvasses Dialogue over Fuel Subsidy Removal”, January 11, 2012). This Guardian news story expresses similar sentiments: "There is no doubt that those engineering this strike are compromised by opposition politicians and beneficiaries of subsidy” (The Guardian, “Elechi, others caution Labour over protest”, Thursday, 12 January 2012). Elechi's allegations were repeated by Rabiu Kwankwaso: "The situation in Kano is now being politicised. Information available to us indicates that there is a calculated attempt by a political party and a faith-based students' body to take control of the situation” (The Punch, "Subsidy: Protests Enter Day Four”, January 6, 2012 by Our Correspondents).

\section{How Were the Causes of the Occupy Nigeria Protests Framed in Newspapers and Social Media?}

The second goal of this paper is to identify the causes of the Occupy Nigeria Protest by using nine content categories. The frames are: injustice, sympathy, legitimizing, delegitimizing, accountability, spectacle, contextual and trust deficit. The unit of analysis - text only—yielded the following figures. Social media: blogs (163), Nairaland (347), Tweets (929) and Facebook (163). The three newspapers had a total frequency count of: Punch (497), Guardian (637) and Tribune (474). The results of each of the two media are displayed in Table 2 below.

\section{How the Causes of Occupy Nigeria Protest Was Framed by the Social Media?}

Comments on Nairaland (32\%), Tweets (41.2\%) and Facebook (60.7\%) had legitimizing frames. The only difference in the social media sample was seen in blogs where "accountability" and "injustice" shared the same frequency (17.2\%).

On Nairaland, these comments by 1st estees and belabela respectively, typify the legitimizing frames. 1st estees: "Ibadan, ours was a success story dis morning. We took off as planned at Makola roundabout by Tantalizers and matched slowly and peacefully. We were joined by students from D Polytechnic (sic) UI.” Belabela was philosophical: "If you will protest courageously, and yet with dignity and Christian love, when the history books are written in future generations, the historians will have to pause and say, 'There lived a great people-a black people who injected new meaning and dignity into the veins of civilization.'-Martin Luther King Jr., address to Holt Street Baptist Church, 5 December 1955”.

The narration by 1st estees and belabela sought recognition or support for the protest and protesters-participant narration. However, the legitimizing frames from Twitter had both support for the protest by non-protesters (foreign or local celebrities and religious leaders) and protesters narrative. For instance, Omojuwa (@omojuwa) tweeted: “Greek Newspaper Publishes \#OccupyNigeria Story and Pictures...”. The second tweet was from MC HAMMER (@MCHammer): “As we celebrate the Honorable Dr King Our Prayers go out to our Brothers and Sisters in Nigeria \#OccupyNigeria”. Nigerian celebrities supported the protest. For instance, Asa (asha) tweeting from @Asa_Official wrote: “Greetings from Australia \#OccupyNigeria”. Another musician, [David Omokekere] Davido (@iamDavido) tweeted: “RT @iamshizzi: Occupying Nigeria with @iamDavido... \#OccupyNigeria”. Although it might be argued that the two celebrities above could safely support the protest "from Australia" (Asa), however, Uche Jombo-Rodriguez - a Nigerian actor made two successive tweets which lays these doubts to rest—@uchejombo: "Those who cannot stand up for a good cause, should be given a good curse! \#OccupyNigeria." Her second tweet read: "This is not a fight against the president or his ministers. It's a fight for what is right. \#OccupyNigeria".

The religious support for the protest came from a revered Bishop, according to this tweet by Pdbraide (@pdbraide): “Catholic Bishop leads fuel protest... petitions Police, SSS 2 b proactive on security...\#Occupy Nigeria". The tweet shared by Pdbraide was a link to a story reported in Daily Post (an online news portal) which reads thus: "Catholic Bishop of Ekiti Diocese, The Most Reverend Felix Femi Ajakaye, was among the protesters in Ado-Ekiti on Monday.” (Daily Post, 2012). 
Table 2 shows that Nairaland (NL) had the highest value for delegitimizing frames as the cause of the protest (13.5\%) when compared to blogs (4.9\%) tweets (3\%) and Facebook (9.2\%). For instance, Ogugua88, a commentator in Nairaland asserts: "and who are supposed to go out? The man who has his kids (sic) school fees to pay? ...I am sorry to burst your bubble but there are many reasons why no protest would work...?” Similarly, Coogar insisted that the protest was uncalled for: "We are wise, dialogue is the way to go...Libya is yet to know peace, same with Egypt”.

Two frames were peculiar to Nairaland. First, although all social media reported the fear of violence (spectacle frames) as the second dominant frame, however only NL commented about the violence associated with the protest. Lucida_ng —an NL commentator—queried: "What's the rationale for burning tires? Thought the idea was to use placards? I just pray that this protest remains peaceful...” Lucida_ng's fears were confirmed by $O y b$ : "they are rioting in Ilorin right now, my dad was attached (sic) while driving and they snatched his handset. Fuckers almost broke his windscreen..." In contrast, Twitter users focused on the celebration mood of protesters. Babatunde Rosanwo (@rosanwo): “\#OccupyNigeria occupying police Hq in carnival like manner in Markurdi...” and Kathleen Ndogngmo (@KatheleenNdongwo): "No retreat. No surrender. Almost all of this (sic) crowd is the 'New Nigeria' “\#OccupyNigeria..." On Facebook, Samuel Stephen-Wakdok stated: "In the next few days, our patience will be tested. This government and her sympathizers will begin to plant moles in our midst to create chaos and then kill the protesters. The idea is to discredit the movement...” Unlike in Nairaland, this Facebook commentator did not attribute that the violence to the protesters, rather he blamed it on conspiracy against the protesters.

Secondly, only in NL did we identify "delegitimizing frames" that were coloured by ethnic divides. Chuksikem blamed the Yoruba’s: “...rubbish, just keep instigating dumb folks; I know your type, typical Yoruba blood, always bolting away at the slightest sound of violence, just the same way your folks did during the Lekki protest". Rich4god accused the Igbo's of cowardice: "what is happening to my brothers in SE, are we just going to swallow the effect without a fight..." On the other hand, Nadanbata said the protest was instigated by northerners: “Aboki don't play o... Waits for someone to come in and ask but what do you contribute to Naija?” [Aboki is an Hausa word meaning friend, but many people in the southern Nigeria use the word to derogatorily refer to Hausas in general.] Mukinawa2 said that northerners believe that the Niger Deltans are inferior: "Stop playing on our intelligence! WE ARE NOT ONE... for now it is a big NO. Hausa is not the head and Niger Delta the tail”.

\section{How the Causes of Occupy Nigeria Protest Was Framed by Newspapers?}

The newspapers expressed similarity in attributing "legitimizing" as the majority cause of the protest-Punch (42.9\%), Guardian (31\%) and Nigerian Tribune (38.8\%). On the other hand, "contextual” frames were the least

\section{Table 2. Causes of the occupy Nigeria protest in social media and newspapers.}

\begin{tabular}{|c|c|c|c|c|c|c|c|c|c|c|c|c|c|c|}
\hline & \multicolumn{8}{|c|}{ Social Media } & \multicolumn{6}{|c|}{ Newspapers } \\
\hline & \multicolumn{2}{|c|}{ Blogs } & \multicolumn{2}{|c|}{ Nairaland } & \multicolumn{2}{|c|}{ Tweet } & \multicolumn{2}{|c|}{ Facebook } & \multicolumn{2}{|c|}{ Punch } & \multicolumn{2}{|c|}{ Guardian } & \multicolumn{2}{|c|}{ Tribune } \\
\hline & $\mathrm{N}$ & (\%) & $\mathrm{N}$ & (\%) & $\mathrm{N}$ & (\%) & $\mathrm{N}$ & (\%) & $\mathrm{N}$ & (\%) & $\mathrm{N}$ & (\%) & $\mathrm{N}$ & (\%) \\
\hline Injustice & 28 & 17.2 & 23 & 6.6 & 89 & 9.6 & 6 & 3.7 & 36 & 7.2 & 24 & 3.8 & 18 & 3.8 \\
\hline Sympathy & 22 & 13.5 & 13 & 3.7 & 93 & 10.0 & 10 & 6.1 & 48 & 9.7 & 40 & 6.3 & 29 & 6.1 \\
\hline Legitimizing & 19 & 11.7 & 111 & 32.0 & 383 & 41.2 & 99 & 60.7 & 213 & 42.9 & 200 & 31.4 & 184 & 38.8 \\
\hline Delegitimizing & 8 & 4.9 & 47 & 13.5 & 28 & 3.0 & 15 & 9.2 & 52 & 10.5 & 111 & 17.4 & 95 & 20.0 \\
\hline Accountability & 28 & 17.2 & 30 & 8.6 & 72 & 7.8 & 15 & 9.2 & 46 & 9.3 & 86 & 13.5 & 33 & 7.0 \\
\hline Spectacle & 8 & 4.9 & 90 & 25.9 & 156 & 16.8 & 6 & 3.7 & 55 & 11.1 & 62 & 9.7 & 57 & 12.0 \\
\hline Contextual & 13 & 8.0 & 10 & 2.9 & 37 & 4.0 & 2 & 1.2 & 6 & 1.2 & 11 & 1.7 & 14 & 3.0 \\
\hline Trust deficit & 26 & 16.0 & 19 & 5.5 & 45 & 4.8 & 6 & 3.7 & 32 & 6.4 & 81 & 12.7 & 35 & 7.4 \\
\hline Imperialism & 11 & 6.7 & 4 & 1.2 & 26 & 2.8 & 4 & 2.5 & 9 & 1.8 & 22 & 3.5 & 9 & 1.9 \\
\hline Total & 163 & 100.0 & 347 & 100.0 & 929 & 100.0 & 163 & 100.0 & 497 & 100.0 & 637 & 100.0 & 474 & 100.0 \\
\hline
\end{tabular}


possible cause of the protests—Punch (1.2\%), Guardian (1.7\%) and Nigerian Tribune (1.9\%). This is an example of legitimizing frame:

Prof. Wole Soyinka said: "Rarely has government alienation from the people it is meant to serve been so (sic) pronounced as demonstrated in the recent removal of the so-called oil subsidy. The bruited palliatives, as illusory as electoral promises, belong to what Nigerians routinely describe as 'medicine after death.' (The Guardian, "Soyinka, Braithwaite, Achebe, others stand with Nigerians in protest”, Monday, January 9, 2013).

We also noticed that newspaper reports had a more balanced narrative than the social media. It was not uncommon, to find two contrasting stories - for or against the protest-in the same reportage. For instance the news story below carried both the sympathy (see first paragraph) and delegitimizing frames (see second paragraph) in the same reportage:

[...] Soldiers from the Presidential Villa under the command of the Commander of Brigade of Guards, Brig. Gen. Emmanuel Atewe, however, dispersed the protesters and arrested their leaders, including Melaye.

[...] The Presidency on Monday insisted that the cost of petrol in the country remained the cheapest in spite of the astronomical hike in its pump price. Presidential spokesman, Reuben Abati said, "This particular announcement had been foretold. Government had prepared the peoples' mind that in 2012 there will be no subsidy on PMS” (Our Correspondents, The Punch, "Fuel Subsidy Removal Stirs Anger, Protests”, January 3, 2012).

In the Punch news story above, expressed both sympathy for the protesters due to harassment from soldiers and at the same time reported a lack of support for the protest by the presidential spokesman. The same is also evident in this news story from the Nigerian Tribune which has both legitimizing and delegitimizing frames reported side-by-side:

On the other hand, the Guardian news story combined both delegitimizing frames and trust deficit frame respectively. This first part of the story shows pro-subsidy removal supporters: "In Ebonyi, there was heavy traffic snarl on major streets of Abakaliki, the state capital yesterday as members of civil society groups numbering about 6,000 marched through the streets to demonstrate their support for the withdrawal of subsidy.” The second part of the same Guardian story focused on the lack of trust as expressed by a leader of National Association of Nigerian Students, Mr Nwachukwu Okpalaoka: “...Nigeria runs the risk of losing the subsidy money to private pockets. The problem is that Nigerians are fast losing confidence in their leaders because of corruption" (The Guardian "Pro-subsidy removal rallies gather momentum", Thursday, 12 January 2012, From Isa Abdulsalami, Willie Etim, Emmanuel Badejo, et al.).

The above examples typify the dominant feature in the newspapers examined in this study, a deliberate effort to give a fair and balanced reportage to both parties. Other frames that were coded in newspaper reportage were injustice and spectacle frames. For instance, the only Editorial written by the Nigerian Tribune addressed the "injustice" afflicted by security agents on some protesters.

The only thing not in dispute is that a young man was killed in Ilorin on Tuesday, 3 January, 2012, during a protest against the increase in the price of petrol. Eyewitness said Muyideeen Mustapha was shot by one of the policemen deployed to keep a wary eye on the protesters, but the Kwara State Commissioner of Police, Mr Peter Gana, said the young man was stabbed by a protester because he refused to join the protest. How did the police commissioner know this? Is the person who allegedly stabbed the deceased in custody and did he confess to the crime? (Nigerian Tribune, Editorial, "The Police and Protesters", January 17, 2012, p. 51).

The Nigerian Tribune could not stand the violation of the right to life of a protester (injustice frame) and demanded justice for the young man who was killed by a policeman. Nonetheless, this same newspaper had a week earlier brought to public notice, the violence and deviance of some protesters (spectacle frame):

Protests in the suburb of Abuja were, however, hijacked by hoodlums, leading to confrontations and road blockades at Kuje, Gwagwalada, Nyanya and other parts of the territory.... The street protests also turned violent in Kano State, on Monday .... In Ibadan, the Oyo State capital, hoodlums took the advantage of the protest and started robbing residents, dispossessing them of their valuables. (Our Reporters, The Nigerian Tribune, "Hoodlums Hijack Protests”, January 11, 2012, p. 4). 
Some staffs of the Guardian newspapers were attacked by protesters: "Two members of staff of Guardian Newspapers Limited (GNL), Mr. Seye Olumide and Mr. Michael Mogaha Ikechukwu, suffered unprovoked attack by purported protesters in Lagos. The duo (sic) is now receiving treatment in a hospital.” (The Guardian "Hoodlums attack The Guardian workers", Thursday, 12 January 2012, Isa Abdulsalami, Willie Etim, Emmanuel Badejo, Bertram Nwannekanma, Joseph Onyekwere, Leo Sobechi, and Uzoma Nzeagwu).

7. How Were The Solutions Advocated to End the Occupy Nigeria Protests Framed in Newspapers and Social Media?

The answers to the third research question above were achieved through a content analysis of texts from social media and newspapers. The eight main content categories coded are: resignation of President Goodluck Ebele Jonathan (GEJ); the sacking of (Ngozi) Okonjo-Iweala (Finance and Coordinating Minister of the Economy); elimination of subsidy, reverting the price of fuel to status quo, investigating, prosecuting and jailing of convicted embezzlers of the subsidy money on fuel. The others are: cutting government spending, institutional reforms and restoring old refineries/building new ones. The table below shows the solutions advanced for ending the protest by the different media.

\section{How the Solutions Advocated for Ending the Occupy Nigeria Protest Were Framed in the Social Media?}

Three social media platforms proposed the "revert to old price" as their primary solution to end the protests: Nairaland (23.2\%), Tweets (35.6\%) and Facebook (32.5\%). Bloggers differed as their main solution was institutional reforms (25.4\%). The second solution advocated was: "revert to old price" blogs (19.3\%); "jailing corrupt people" Nairaland (22.2\%); "Institutional reforms" twitter (19.3\%) and on Facebook it was "jailing corrupt people" (27.5\%).

We will begin our unpacking of the numbers in Table 3 by providing qualitative data. Canary! (@ogundamisi) tweeted: "NLC/TUC to Nigerian Senate. WE SHALL CALL OFF STRIKE ONLY WHEN PRICE IS RETURNED TO FORMER PRICE... \#OccupyNigeria". This blog post asserts that: "The Convener of the Save Nigeria Group (SNG), Pastor Tunde Bakare; Human Rights Lawyer, Mr. Femi Falana; and Founder of O’odua People's Congress (OPC), Dr. Fredrick Fasheun, along with other activists and artistes on (sic) yesterday in Lagos, asked President Goodluck Jonathan to resign or revert the pump price of fuel to N65 per litre.” (Jobbers, The Info Strides "Situation Reports: Nigerian Fuel Subsidy Removal Protests”, January 10, 2012).

This is a sampler of the social media position; revert to old price or nothing. Netizens were rigid because government had not addressed the corruption in petroleum industry and excess government spending.

The first argument by social media users were typified with these posts on Facebook, by Sani Garba Mohammed: "we do not need any compromise; it is either N65 or lower. NLC/TUC, don’t cave in". Similarly Tijjani Muhammad Musa said: "N65/litre of petrol is no more acceptable! ...we must not accept this reversal back (sic) to that price..." Chiebuka Nworah shared this: "We have to say no to fuel subsidy removal and to corruption. The leaders are ready to once again allow the masses to pay for their corruption and gross misma-

Table 3. Solutions advocated to end the occupy Nigeria protest.

\begin{tabular}{|c|c|c|c|c|c|c|c|c|c|c|c|c|c|c|}
\hline & \multicolumn{8}{|c|}{ Social Media } & \multicolumn{6}{|c|}{ Newspapers } \\
\hline & \multicolumn{2}{|c|}{ Blogs } & \multicolumn{2}{|c|}{ Nairaland } & \multicolumn{2}{|c|}{ Tweet } & \multicolumn{2}{|c|}{ Facebook } & \multicolumn{2}{|c|}{ Punch } & \multicolumn{2}{|c|}{ Guardian } & \multicolumn{2}{|c|}{ Tribune } \\
\hline & $\mathrm{N}$ & (\%) & $\mathrm{N}$ & (\%) & $\mathrm{N}$ & (\%) & $\mathrm{N}$ & (\%) & $\mathrm{N}$ & (\%) & $\mathrm{N}$ & (\%) & $\mathrm{N}$ & (\%) \\
\hline GEJ Resignation & 4 & 3.5 & 1 & 1.2 & 3 & 2.2 & 0 & 0.0 & 6 & 3.3 & 6 & 1.7 & 2 & 0.9 \\
\hline Sack Iwella & 3 & 2.6 & 1 & 1.2 & 4 & 3.0 & 0 & 0.0 & 2 & 1.1 & 2 & 0.6 & 3 & 1.3 \\
\hline Eliminate Subsidy & 7 & 6.1 & 8 & 9.8 & 13 & 9.6 & 2 & 5.0 & 26 & 14.4 & 60 & 17.2 & 62 & 26.7 \\
\hline Revert to Old Price & 27 & 23.7 & 19 & 23.2 & 48 & 35.6 & 13 & 32.5 & 80 & 44.4 & 91 & 26.1 & 110 & 47.4 \\
\hline Jailing Corrupt People & 14 & 12.3 & 18 & 22.0 & 17 & 12.6 & 11 & 27.5 & 21 & 11.7 & 49 & 14.0 & 20 & 8.6 \\
\hline Cut Spending & 22 & 19.3 & 16 & 19.5 & 22 & 16.3 & 6 & 15.0 & 26 & 14.4 & 58 & 16.6 & 13 & 5.6 \\
\hline Institutional Reforms & 29 & 25.4 & 10 & 12.2 & 26 & 19.3 & 5 & 12.5 & 8 & 4.4 & 46 & 13.2 & 13 & 5.6 \\
\hline Refineries & 8 & 7.0 & 9 & 11.0 & 2 & 1.5 & 3 & 7.5 & 11 & 6.1 & 37 & 10.6 & 9 & 3.9 \\
\hline Total & 114 & 100.0 & 82 & 100.0 & 135 & 100.0 & 40 & 100.0 & 180 & 100.0 & 349 & 100.0 & 232 & 100.0 \\
\hline
\end{tabular}


nagement.” ‘Gbenga Sesan (@gbengasesan) tweeted: “N1.4Tr in subsidy payments is a lie! Our government is wasteful, not serious about fighting corruption! \#OccupyNigeria".

Another argument by the government was that of a 'cabal' running the importation of petrol. DaLover in NL claims that: "3 individuals or families have been identified as major marketers, Adenuga, Tinubu and Otedola". Samuel Stephen-Wakdok commented on Facebook: "government cannot deal with corruption or is not willing to confront their buddies that are the 'cabal'. Was Femi Otedola (the Diesel Prince) not the biggest sponsor of the President's ambition in 2011?” Thus protesters were angry with these fuel importers, Eggheader Odewale (@eggheader): "FLASH: Today \#OccupyNigeria protesters besieged d Lagos houses of Femi Otedola, Oba Otudeko and Wale Tinubu...." The protesters also wanted them prosecuted. Alj_harem commented on NL: "Worse still, government (sic) failure to tackle the 'cabal' which it claims at every instance is responsible for colossal fraud in oil importation and its failure to revamp the refineries..."

The second factor responsible for the rigidity of "reversal to old price" frame was "cutting government spending”. 'Seun Fakuade (@seunfakze) was sarcastic: “OBAMA TO REDUCE SIZE OF GOVT. Jonathan see your mentor!!!... \#OccupyNigeria”. Sturvs Man (@sturvs) said: “N1 billion for feeding? Do u eat Louis vuitton rice and Gucci beans??? \#OccupyNigeria". Profosahon, a Nairaland commentator asserts that: "We cannot tighten our belts when he cannot do same. Jonathan cut these outrageous expenditures and use the savings to fix our power and transport infrastructures...”

The above qualitative data and numbers in Table 3 explains why social media was rigid in their prognosis of "revert to old price" as a solution in ending the Occupy Nigeria protest. Consequently, their insistence on curbing government expenditure can be more clearly understood.

Table 3 shows that bloggers hinged the primary solution to end the protest on the "institutional reforms" frame. For instance Nneka (a blogger) suggested that protesters should: "Draw up a list of priorities that can be realistically accomplished in the next twenty-four months. These priorities should lay a foundation that allows for Nigerians to easily mitigate the effect of a full/partial deregulated downstream sector..." (Nneka, Personal Views, "Fuel Subsidy: When the Return to status quo is not the Victory Desired!” Thursday, January 12, 2012). In the end, it boiled down to a lack of trust - that the funds saved from the removed subsidy might be misappropriated.

\section{How the Solutions Advocated for Ending the Occupy Nigeria Protest Were Framed in Newspapers?}

Like the social media platforms, the Punch (44.4\%), Guardian (26.1\%) and Nigerian Tribune (47.4\%) also presented the solution of "reverting to the old price". Their second option was the "eliminating subsidy" frame. However, Punch shared this second option with the "cutting government expenses" (14.4\%); Guardian (17.2\%) and Nigerian Tribune (26.7\%). The newspapers did not see the "resignation of GEJ" or the "sacking of Iwella" as reasonable solutions to resolve the conflict. Their values are revealing: Punch (1.1\%); Guardian (0.6\%) and Nigerian Tribune (0.9\%).

However, the figures above do not narrate events that lead to the end of the protests. The Occupy Nigeria Protest was a reaction to the elimination of subsidy on PMS. Government insisted that there was no other alternative while labour and social movement organisations disagreed. "Governors of the 36 states of the federation have said that there was no alternative to deregulation of the downstream of petroleum industry to guarantee a better future for the country" (Leon Usigbe, "No alternative to subsidy removal-Govs" Nigerian Tribune, Sunday, 08 January 2012). However, labour and SMOs insisted on reducing excess government spending rather than removing the fuel subsidy: "What about the cost of governance and the financial burden to the people of Nigeria of Nigeria's brand of democracy-the undeserved super jumbo wages, allowances and perks for every so-called 'elected' (though not elected) of the cartels in the executive and the legislative arms of government in Nigeria?” (The Guardian, "Soyinka, Braithwaite, Achebe, others stand with Nigerians in protest” Monday, 09 January 2012).

The intensity of the protests and the insistence on government to cut its expenditure, led to a national broadcast by President Goodluck Jonathan. The president reaffirmed the irreversibility of the price increase but proposed to cut government spending.

On the part of government, we are taking several measures aimed at cutting the size and cost of governance, including on-going and continuous effort to reduce the size of our recurrent expenditure and increase capital spending. For the year 2012, the basic salaries of all political office holders in the executive arm of government will be reduced by 25\% (President Goodluck Jonathan, "We'll Reduce Cost of Governance, Says President” Guardian, Sunday, 08 January 2012). 
Nonetheless the president's proposal did not convince the protesters. Many believed that he was not sincere:

But while it is calling on Nigerians to sacrifice for a better future, the government itself is not willing to curb its own extravagance and waste, as components in the 2012 budget proposal currently awaiting the approval of the National Assembly have shown (Editorial Board, Punch "Fuel Subsidy and Waste in Budgeting”, January 5, 2012).

As the protests progressed, even supporters of fuel subsidy elimination also asked government to cut its expenses and fight corruption in the petroleum industry.

The National Youth Council of Nigeria (NYCN) has said that the removal of fuel subsidy will revamp the various sectors in the nation's economy by stimulating foreign investment... The council, therefore, called on the Federal Government to immediately commence serious probing and sanitisation of the oil sector in order to properly utilise funds accruable from the deregulation policy (Nigerian Tribune "NYCN Backs Subsidy Removal” January 11, 2012)

Civil societies groups, however, remained adamant on the reversal of the fuel subsidy: "A coalition of civil society groups have insisted that a return to the N65 per litre for petrol will be the only basis for calling off street protests and demonstrations, to give room for further negotiations..." (John Alechenu, Emmanuel Obe and Allwell Okpi, Punch, "It’s N65 per litre or nothing-Civil groups" January 15, 2012).

The Occupy Nigeria Protest, it would be recalled was championed by labour and civil liberty groups. Eventually only government and labour took the path of compromise: "The NLC president, Comrade Abdulwaheed Omar told State House correspondents that the Federal Government and NLC were prepared to shift grounds" (Leon Usigbe, Olawale Rasheed and Jacob Segun Olatunji, Nigerian Tribune, "Subsidy: FG, Labour Makes Progress, Agree To Shift Grounds, Meet Again On Saturday, Labour Orders Workers to Continue Strike”, Abuja Friday, 13 January 2012). Thus in the early hours of January 16, 2012, President Jonathan in an national broadcast reduced the price of petrol from N140 to N97, the original price before the elimination of subsidy was N65. The president said: "government has approved the reduction of the pump price of petrol to N97 per litre" (Full Text of President Goodluck Jonathan Address to the Nation, The Punch "Petrol now N97 per litre" January 16, 2012). Later that same day the leaders of Nigeria Labour Congress (NLC) and Trade Union Congress (TUC) suspended their industrial action and directed that the cessation of protests: "Labour and its allies formally announce the suspension of strikes, mass rallies and protests across the country" (Press Conference by NLC and TUC presidents, Abdulwaheed Omar and Peter Esele "Suspension of Strikes and Mass Protests against Hike in Fuel Prices” The Guardian Monday, 16 January 2012).

\section{Discussion and Conclusions}

Both newspapers and social media defined the protest as mass movement. SMOs have to justify their call to arms and this is important in mobilisation. However, this concordance between newspaper and social media definition rejects the thrust of asymmetrical dependency which has pitched movements at the mercy of old media. The newspapers also accused opposition politicians as the reason for the protest. This was justifiable because some vocal leaders of the civil society part of the Occupy Nigeria Protests were opposition politicians. For instance, Tunde Bakere, Dino Melaye and Nasir El-Rufai, are members of the opposition and vocal critiques of the ruling party. On the other hand, social media differed from newspapers with the predominance of generational frame. This is understandable since social media users want to recreate a Nigerian version of the Arab Spring. As such pictures of Christians forming a ring around praying Muslims or Muslims guarding Christian churches, same as what happened during the Egypt uprising, went viral on social media platforms. Finding also showed that social media protesters tried to mimic the Arab Spring occupation with phrases like: "Kano Liberation Square is turning into Tahrir Square in Egypt", "Slowly but certain, Kano may become the Benghazi of Nigeria" or "The Gani Fawehinmi Freedom Park at Ojota is indeed the Nigerian equivalent of the popular Tahrir Square occupation in Egypt" [4]. On the other hand, newspapers used the other popular definition like oppression and government insensitivity. This is understandable since the protest took place soon after the Boko haram terrorists bombed some churches in Abuja, the capital city of Nigeria on Christmas Day.

Findings show that both newspapers and social media validated the protest, their message and offered support to them. However, it was strange that the social media promoted the violence and protesters' deviant behaviour. This has been the exclusive preserve of traditional media and is one of the reasons for the asymmetrical media 
imbalance against movements. We think that the social media activists tended to emphasise the support that the protest enjoyed but went overboard by over focusing on the emotion and drama of protesters. Yet the balanced reportage by newspapers was confirmed with their second largest diagnosis of the protest, the delegitimizing frames. This not only confirmed their pluralism but also comparatively showed a lack of it in social media.

Both media showed concord in the solution of first choice they proposed to end the conflict which was the reversal of the price increase to its original cost. However, the gulf between newspapers and social media framing is seen in their second and third choices. The social media activists insisted on annihilating corruption in the petroleum industry and cutting government as a perquisite to withdrawing subsidy on PMS. On the other hand, journalists were more practical with a call for both parties in the conflict to seek a compromise. In the end, the crisis was resolved by both government and labour's adoption of a mean position, which leads to the end of the protest. Thus newspapers revealed a maturity that tempered the ideal with reality. This is essential in conflict resolution and always heralds peace. Unfortunately, the social media activists were obstinate in their long term solutions which left them to only refute solutions advocated by others without offering a better alternative.

In summary, the Occupy Nigeria Protests had similarities in the first choice of frames that defined, attributed causes and proposed solutions for the demonstrations. However, the differences in other predominant frames revealed that traditional media was more faithful to the message of the protest than social media. Social media users were either trying to impose an Arab Spring on Nigeria, showing the strength of their crowd but inadvertently hyping the violence or emotional drama or they were too idealistic in proposing a solution. On the other hand, journalists consistently offered the many sides of the protests. As much as newspapers did not deny government insensitivity as the trigger to the mass action, they also revealed how opposition politics defined the movement. The causes of the protests were not limited to validating the protesters, but often time placed side-by-side with contrary opinions that did not support the protest. The journalists' fair and balanced reportage was also the reason for the compromised they advocated between labour and government. This was absent in the social media narration, which were homogenous and lacked plurality.

As Nigeria deepens her democratic experience, there will be more movements that seek to effect a change or force government to reverse a policy. This study has shown that SMOs should only engage entities that share similar mission with them as the joint collaboration with labour is a disaster. Also movements should effectively engage traditional and social media. Civil societies over reliance on social media in the Occupy Nigeria protests diminish collective identity and crown individualism.

This paper does not have the last word on protests in Nigeria as we are unable to investigate the regional nuances and frames due to the unavailability of local newspapers we have intended to include as samples. Nonetheless, we hope that this study will serve as a catalyst for further investigation on framing, social movement/ media research in Nigeria and sub-Saharan Africa.

\section{References}

[1] African Urbanism (2012) Protests, Fuel Subsidy Removal and the Role of Social Media: Not Just Another Day in Nigeria. African Urbanism: A Blog, January 5, 2012.

[2] Adewole, I. and Ogunde, O. (2012) The Nigerian General Strike Heralds a Revolutionary Process. 16 January 2012 http://www.marxist.com/nigerian-general-strike-heralds-revolutionary-process.htm

[3] Bociurkiw, M. (2012) “Occupy” Protests Become Major Challenge to Nigerian Government. Huffington Post. http://www.huffingtonpost.com/michael-bociurkiw/nigeria-occupy-protests_b_1183907.html

[4] Campbell, J. (2012) \#Occupy Nigeria. The World from African Perspective, January 7, 2012. http://newafricanpress.com/2012/01/07/occupy-nigeria/

[5] Global Press Institute (2012) Nigerians Wield Social Media During Fuel Subsidy Protests. http://www.dailykos.com/story/2012/03/05/1071187/-Nigerians-Wield-Social-Media-During-Fuel-Subsidy-Protests

[6] Fripp, C. (2012). Social Media Fans the Nigerian Fuel Subsidy Debate. IT News Africa, January 2012. http://www.itnewsafrica.com/2012/01/social-media-fans-the-nigerian-fuel-subsidy-debate/

[7] Itua, F. (2012) Subsidy Protest and the Power of Social Media. Leadership, January 14, 2012. http://allafrica.com/stories/201201161238.html

[8] Onwuegbuchi, C. (2012) How Social Media Fuelled “Occupy Nigeria” Protests. Nigeria Communications Week, February 6, 2012.

http://www.nigeriacommunicationsweek.com.ng/news/how-social-media-fueled-occupy-nigeria-protests 
[9] Usman, Z. (2012) The Pains and Gains of \#OccupyNigeria Movement. Nigerians Talk, January 23, 2012. http://nigerianstalk.org/2012/01/23/the-pains-and-gains-of-occupynigeria/

[10] Vlam, P. (2012) Social Media Inspires Nigerian Protests. Radio Netherlands Worldwide African Desk, January 12, 2012. http://allafrica.com/stories/201201121072.html

[11] Frequently Asked Questions on Deregulation of the Downstream Petroleum Sector and Removal of Petroleum Subsidy (Undated). Prepared by the Office of the Chief Economic Adviser to the President in collaboration with the NNPC, and the Budget Office of the Federation, 7-8. http://www.fmf.gov.ng/component/content/article/3-trendingnews/63-faqfuelsubsidy.html

[12] Ogbuefi Blogs (2012) Sanusi Lamido Sanusi: Why I Support the Removal of Fuel Subsidy. Elombah News, January 05, 2012. http://www.elombah.com/index.php/special-reports/9337-sanusi-lamido-sanusi-why-i-support-the-removal-of-fuel-sub sidy

[13] Egbunike, N.A. (2010) Nigeria’s Years of Broken Promises. Nigerian Tribune, April 8, 2010.

[14] OMG (2012) The Impact of the Fuel Subsidy Removal so far on the Nigerian Economy. OMG Reporter, January 16, 2012. http://www.omgnaija.com/2012/01/the-impact-of-the-fuel-subsidy-removal-so-far-on-the-nigerian-economy/

[15] Clottey, P. (2012) Nigeria Strike to Proceed Monday despite Court Order. VOA (Voice of America), January $07,2013$. http://m.voanews.com/a/159428.html

[16] Onyishi, A.O., Eme, O.I. and Emeh, I.E. (2012) The Domestic and International Implications of Fuel Subsidy Removal Crisis in Nigeria. Kuwait Chapter of Arabian Journal of Business and Management Review, 1, 57-80. http://www.arabianjbmr.com/pdfs/KD_VOL_1_6/5.pdf

[17] Ogunlesi, T. (2012) The Fuel Subsidy has Woken Nigerians Up. The Guardian (UK), January 11, 2012. http://bit.ly/x9ufQp

[18] Gitlin, T. (1980) The Whole World Is Watching: Mass Media in the Making and Unmaking of the New Left. University of California Press, Berkeley.

[19] Entman, R. (1993) Framing: Toward Clarification of a Fractured Paradigm. Journal of Communication, 43, 51-58. http://dx.doi.org/10.1111/j.1460-2466.1993.tb01304.x

[20] McCombs, M.E. and Shaw, D.L. (1972) The Agenda-Setting Function of Mass Media. Public Opinion Quarterly, 36, 176-187. http://dx.doi.org/10.1086/267990

[21] Benford, R.D. and Snow, D.A. (2000) Framing Processes and Social Movements: An Overview and Assessment. Annual Review of Sociology, 26, 611-639. http://dx.doi.org/10.1146/annurev.soc.26.1.611

[22] Cissel, M. (2012) Media Framing: A Comparative Content Analysis on Mainstream and Alternative News Coverage of Occupy Wall Street. The Elon Journal of Undergraduate Research in Communications, 3, 67-77.

[23] Kutz-Flamenbaum, R.V., Staggenborg, S. and Duncan, B.J. (2012) Media Framing of the Pittsburgh G-20 Protests. Research in Social Movements, Conflicts and Change, 33, 109-135. http://dx.doi.org/10.1108/S0163-786X(2012)0000033008

[24] Phipps, K. and Szagala, K. (2007) Social Movements and the News Media. The McMaster Journal of Communication, 4, 31-55.

[25] Castells, M. (2007) Communication, Power and Counter-Power in the Network Society. International Journal of Communication, 1, 238-266.

[26] Barassi, V. (2009) Digital vs. Material: The Everyday Construction of Mediated Political Action. Networking Knowledge: Journal of the MeCCSA Postgraduate Network, 1, 1-15.

[27] Garrett, R.K. (2006) Protest in an Information Society: A Review of Literature on Social Movements and New ICTs. Information, Communication and Society, 9, 202-224. http://dx.doi.org/10.1080/13691180600630773

[28] Gerhards, J. and Schäfer, M.S. (2009) Is the Internet a Better Public Sphere? Comparing Old and New Media in the US and Germany. New Media and Society, 20, 1-18.

[29] Shirky, C. (2011) The Political Power of Social Media. Foreign Affairs, January/February 2011. http://www.foreignaffairs.com/articles/67038/clay-shirky/the-politicalpower-of-social-media

[30] Douai, A. and Moussa, M.B. (2013) Twitter Frames: Finding Social Media’s “Influentials” during the “Arab Spring”. In: Olorunnisola, A.A. and Douai, A., Eds., New Media Influence on Social and Political Change in Africa, IGI Global, Hershey PA, 202-217. http://dx.doi.org/10.4018/978-1-4666-4197-6.ch012

[31] Olorunnisola, A.A. and Martin, B.L. (2013) Influences of Media on Social Movements: Problematizing Hyperbolic Inferences about Impacts. Telematics \& Informatics, 30, 275-288. http://dx.doi.org/10.1016/j.tele.2012.02.005

[32] Hamdy, N. and Gomaa, E.H. (2012) Framing the Egyptian Uprising in Arabic Language Newspapers and Social Media. 
Journal of Communication, 62, 195-211. http://dx.doi.org/10.1111/j.1460-2466.2012.01637.x

[33] Tufekci, Z. and Wilson, C. (2012) Social Media and the Decision to Participate in Political Protest: Observations from Tahrir Square. Journal of Communication, 62, 363-369. http://dx.doi.org/10.1111/j.1460-2466.2012.01629.x

[34] Aouragh, M. and Alexander, A. (2011) The Egyptian Experience: Sense and Nonsense of the Internet Revolution. International Journal of Communication, 5, 1344-1358.

[35] Harlow, S. and Johnson, T.J. (2011) Overthrowing the Protest Paradigm? How the New York Times, Global Voices and Twitter Covered the Egyptian Revolution. International Journal of Communication, 5, 1359-1374.

[36] Chebib, N.K. and Sohail, R.M. (2011) The Reasons Social Media Contributed to the 2011 Egyptian Revolution. International Journal of Business Research and Management (IJBRM), 2, 19-162.

[37] Lim, M. (2012) Clicks, Cabs and Coffee Houses: Social Media and Oppositional Movements in Egypt, $2004-2011$. Journal of Communication, 62, 231-248. http://dx.doi.org/10.1111/j.1460-2466.2012.01628.x

[38] Papacharissi, Z. and Oliveira, M. (2012) Affective News and Networked Publics: The Rhythms of News Storytelling on \#Egypt. Journal of Communication, 62, 266-282. http://dx.doi.org/10.1111/j.1460-2466.2012.01630.x

[39] Holsti, O. (1969) Content Analysis for the Social Sciences and Humanities. Addison-Wesley, Reading.

[40] Adichie, C.N. (2012) A Country’s Frustration, Fuelled Overnight. The New York Times, January 16, 2012. http://www.nytimes.com/2012/01/17/opinion/nigerias-latest-frustration.html?_r=2 